\title{
Excess energy intake promotes the development of hypoalbuminaemia in rats fed on low-protein diets
}

\author{
By P. G. LUNN AND S. AUSTIN \\ Medical Research Council, Dunn Nutrition Unit, Milton Road, Cambridge CB4 $1 X J$
}

(Received 19 March 1982-Accepted 30 June 1982)

\begin{abstract}
1. A group of rats were given ad lib. a diet with a protein-energy: total energy (P:E) value of $0 \cdot 03$. Other animals received the same protein intake $(\mathrm{g} / \mathrm{kg}$ body-weight per $\mathrm{d}$ ) as this group, but had their energy consumption reduced to either $90,80,70,60$ or $50 \%$ of the $a d$ lib. value.

2. The restricted growth rate of rats fed on the P:E - 0.03 diet ad lib. has been shown to be due entirely to their insufficient protein consumption. In contrast, energy intake was far in excess of that required for maintenance and the limited amount of growth.

3. Carcass analysis demonstrated that some of the excess energy intake was stored as fat, but a greater part had been dissipated, presumably by diet-induced thermogenesis.

4. The plasma concentration of triiodothyronine $\left(T_{3}\right)$ was elevated in all animals consuming excess energy and was significantly related to both the total surplus and the amount of energy dissipated.

5. In the group of animais restricted to $50 \%$ of the ad $l i b$. intake, energy rather than protein appeared to be the factor limiting growth. Energy intake was below estimated requirements for maintenance and was associated with values for plasma $T_{3}$ that were lower than those found in well-fed control rats.

6. Although all the animals had similar protein intakes, plasma albumin concentration differed between the groups and was found to be inversely proportional to the energy intake. Thus it was lowest in animals receiving food $a d l i b$. and rose to near normal values in the most-severely-restricted rats.

7. It is suggested that hypoalbuminaemia, and perhaps other features of protein deficiency, seen in animals fed on low-P: E diets may occur as an undesirable consequence of the metabolic response required to deal with excess energy consumption.
\end{abstract}

It has become generally accepted that rats offered diets of low-protein content voluntarily reduce their food intake and thus suffer from a shortage of energy as well as protein. It has been argued, therefore, that it is difficult to know whether the metabolic abnormalities seen in such animals are a result of the low protein-energy: total energy $(\mathrm{P}: \mathrm{E})$ value of the diet, or occur as a response to the voluntary food restriction. However, the findings of Coward et al. (1977) showed that food consumption, when expressed as a function of body-weight, was not reduced in rats maintained on diets of low $\mathrm{P}: \mathrm{E}$ despite severely-restricted growth rates. Moreover, a theoretical estimation of energy requirements for maintenance and growth (using the values of Evans \& Miller, 1968) suggests that far from being short of energy, the animals may be facing the problem of how to deal with a surplus.

The present paper describes a practical investigation into the relative deficiencies and excesses of protein and energy consumed by rats offered ad lib. a low-P:E diet. The relationship between these dietary constituents and plasma albumin concentration, an accepted index of protein deficiency, is also examined.

\section{EXPERIMENTAL}

Males from a specific-pathogen-free colony of hooded rats kept at the Dunn Nutrition Laboratory were used in the experiment. Fifty animals were weaned at 3 weeks on to a synthetic diet of P:E $0 \cdot 20$, on which they were maintained for a further 2 weeks. After this time, they were randomly assigned to six experimental groups of five and two control groups of ten. Rats in one of the control groups were immediately killed to provide baseline values for a carcass composition study. 
Animals in experimental group 1 received a diet of $P$ : E $0.03 \mathrm{ad}$ lib. Those in groups 2-6 were given the same amount of protein as that consumed by group 1 rats (on a body-weight basis), but with progressively greater restrictions of energy. This was achieved by making up a series of isoenergetic diets of P: E $0.0333,0.0375,0.0429,0.0500$ and 0.0600 'nd feeding these at $90,80,70,60$ and $50 \%$ of the intake of the group 1 animals respectively (see Table 1). The remaining ten control animals continued to be fed on the P:E $-0 \cdot 20$ weaning diet. A general description of the basic dietary composition is given by Lunn et al. (1976).

After $14 \mathrm{~d}$ of these dietary treatments, the animals were killed by exsanguination under diethylether anaesthesia. The blood was weighed and heparinized plasma prepared and stored at $-20^{\circ}$ until analysed.

Carcass fat and fat-free dry weight (FFDW) were calculated from estimates of total body water measured directly by desiccation (for a review, see Sheng \& Huggins, 1979). A correction was made for the weight of blood taken for analysis, which was found on average to contain $190 \mathrm{~g}$ solid material $/ \mathrm{kg}$. It was assumed that water constituted $732 \mathrm{~g} / \mathrm{kg}$ fat-free wet weight of the animals, and that protein constituted $800 \mathrm{~g} / \mathrm{kg}$ FFDW (Pace \& Rathbun, 1945).

Triiodothyronine $\left(\mathrm{T}_{3}\right)$ was measured by radioimmunoassay using a kit obtained from The Radiochemical Centre, Amersham, Bucks. Plasma albumin was determined with bromocresol green (Northam \& Widdowson, 1967).

\section{RESULTS}

Rats given the P:E 0.03 diet ad lib. ate, on average, $135.1 \mathrm{~g}$ food $/ \mathrm{kg}$ body-weight per $\mathrm{d}$. This contained $4 \cdot 1 \mathrm{~g}$ protein, and the mean ( $\pm \mathrm{SE}$ ) weight gain over the $14 \mathrm{~d}$ experimental period was $0 \cdot 74 \pm 0 \cdot 13 \mathrm{~g} / \mathrm{d}$, a value much lower than that of control animals, $5 \cdot 43 \pm 0.09 \mathrm{~g} / \mathrm{d}$. Table 1 shows, however, that so long as the protein intake was maintained at $4 \cdot 1 \mathrm{~g} / \mathrm{kg}$ body-weight per d, energy consumption could be reduced to $60 \%$ of the ad lib. intake with only a small and non-significant further reduction in growth rates. A more pronounced and significant fall in growth was observed between groups given 60 and $50 \%$ of the ad lib. energy intake.

Carcass analysis showed, however, that some changes in body composition had occurred (Table 2). FFDW gain was not reduced by lowering energy to $60 \%$ of ad lib. intake; in fact animals in groups 3, 4 and 5 showed slightly better gains than those seen in group 1 . Only in the most-severely-restricted animals (group 6), was a mean reduction in FFDW observed. In contrast, there were marked differences in carcass fat content. In addition to the gain which could be attributed to growth, rats in groups 1-4 showed an increased proportion of body fat. Expressed as a percentage of body-weight, fat was found to have increased by (mean $\pm \mathrm{SE}$ ) $4 \cdot 9 \pm 0 \cdot 9,4 \cdot 3 \pm 0 \cdot 8,1 \cdot 4 \pm 0 \cdot 8$ and $0 \cdot 1 \pm 0 \cdot 6$ in groups $1-4$ respectively. In groups 5 and 6 , some reduction in body fat stores was evident.

\section{Balance studies}

In order to obtain a clearer picture of the relative deficiencies and excesses of the various diets, an examination of the protein and energy balance of the animals was carried out. The results are presented in Table 3 but, in order to calculate the results, a number of assumptions were necessary and were as follows. To obtain the carcass energy content, fat was assumed to represent $39.3 \mathrm{~kJ} / \mathrm{g}$ and FFDW $18.8 \mathrm{~kJ} / \mathrm{g}$ (Canolty \& Koong, 1976). Maintenance requirements for nitrogen and energy for the strain of rats used, and under similar experimental conditions, have been found to be $243 \times$ body-weight $(\mathrm{W})^{0 \cdot 75} \mathrm{mg} \mathrm{N} / \mathrm{d}$ and $586 \times \mathrm{W}^{0.75} \mathrm{~kJ} / \mathrm{d}$ respectively, and the cost of energy deposition to be $10.8 \mathrm{~kJ} / \mathrm{kJ}$ deposited. Protein was calculated as $\mathrm{N} \times 6.25$.

The protein balance results confirm that the low consumption of this nutrient was 
Table 1. The effect of energy restriction on weight gain of rats receiving a constant level of protein

\begin{tabular}{|c|c|c|c|c|c|}
\hline \multirow{2}{*}{$\begin{array}{c}\text { Group } \\
\text { no. }\end{array}$} & \multirow{2}{*}{$\begin{array}{l}\text { Protein intake } \\
\text { (g/kg rat per } d)\end{array}$} & \multirow{2}{*}{$\begin{array}{c}\text { Energy intake } \\
(\mathrm{kJ} / \mathrm{kg} \text { rat per } \mathrm{d})\end{array}$} & \multirow{2}{*}{$\begin{array}{l}\text { Protein-energy: } \\
\text { total energy }\end{array}$} & \multicolumn{2}{|c|}{ Wt gain $(\mathrm{g} / \mathrm{d})$} \\
\hline & & & & Mean & $\mathrm{SE}$ \\
\hline 1 & $4 \cdot 1$ & 2108 & 0.0300 & $0 \cdot 74$ & $0 \cdot 13$ \\
\hline 2 & $4 \cdot 1$ & 1897 & 0.0333 & 0.73 & 0.22 \\
\hline 3 & $4 \cdot 1$ & 1686 & 0.0375 & 0.65 & 0.09 \\
\hline 4 & $4 \cdot 1$ & 1475 & 0.0429 & 0.62 & 0.04 \\
\hline 5 & $4 \cdot 1$ & 1264 & 0.0500 & 0.46 & 0.07 \\
\hline 6 & $4 \cdot 1$ & 1054 & 0.0600 & -0.19 & $0.31^{*}$ \\
\hline Control & $23 \cdot 4$ & 1953 & $0 \cdot 2000$ & $5 \cdot 43$ & 0.9 \\
\hline
\end{tabular}

* Value significantly different from group 1 value: $P<0.05$ (Student's $t$ test).

Table 2. Changes in carcass composition in response to dietary treatments

\begin{tabular}{|c|c|c|c|c|c|c|c|c|c|c|c|c|}
\hline \multirow{3}{*}{$\begin{array}{c}\text { Group } \\
\text { no. } \dagger\end{array}$} & & & & & \multicolumn{4}{|c|}{ Carcass FFDW (g) } & \multicolumn{4}{|c|}{ Carcass fat (g) } \\
\hline & \multicolumn{2}{|c|}{ Body-wt (g) } & \multicolumn{2}{|c|}{ Body water $(\%)$} & \multirow[b]{2}{*}{ Initial† } & \multirow[b]{2}{*}{ Final } & \multicolumn{2}{|c|}{ Change } & \multirow[b]{2}{*}{ Initial } & \multirow[b]{2}{*}{ Final } & \multicolumn{2}{|c|}{ Change } \\
\hline & Mean & SE & Mean & SE & & & Mean & $\mathrm{SE}$ & & & Mean & SE \\
\hline 1 & $109 \cdot 2$ & $1 \cdot 4$ & $65 \cdot 3$ & 0.7 & $25 \cdot 0$ & $26 \cdot 1$ & $1 \cdot 1$ & $0 \cdot 3$ & 5.85 & $10 \cdot 87$ & $5 \cdot 02$ & 0.63 \\
\hline 2 & $111 \cdot 4$ & $3 \cdot 0$ & $65 \cdot 4$ & 0.4 & $26 \cdot 2$ & $27 \cdot 1$ & 0.9 & $0 \cdot 1$ & 6.03 & $11 \cdot 45$ & $5 \cdot 42$ & 0.85 \\
\hline 3 & $108 \cdot 2$ & $3 \cdot 2$ & 67.9 & $0.5^{*}$ & $25 \cdot 0$ & 26.9 & 1.9 & $0 \cdot 3$ & $5 \cdot 90$ & $9 \cdot 04$ & $3 \cdot 14$ & $0 \cdot 23^{*}$ \\
\hline 4 & $112 \cdot 8$ & $2 \cdot 4$ & $68 \cdot 9$ & $0 \cdot 5^{* * *}$ & $26 \cdot 3$ & $28 \cdot 5$ & $2 \cdot 2$ & $0 \cdot 1^{*}$ & $6 \cdot 10$ & $6 \cdot 74$ & 0.64 & $0.72^{* * *}$ \\
\hline 5 & $108 \cdot 2$ & $2 \cdot 8$ & $70 \cdot 2$ & $0 \cdot 6^{* * *}$ & $25 \cdot 7$ & $27 \cdot 8$ & $2 \cdot 1$ & $0 \cdot 1^{*}$ & $5 \cdot 95$ & $4 \cdot 54$ & $-1 \cdot 41$ & $0.89^{* * *}$ \\
\hline 6 & $113 \cdot 2$ & 1.9 & $70 \cdot 0$ & $0 \cdot 5^{* * *}$ & $28 \cdot 3$ & $28 \cdot 3$ & $-0 \cdot 2$ & $1 \cdot 0$ & 6.61 & $4 \cdot 84$ & $-2 \cdot 03$ & $0.75^{* * *}$ \\
\hline
\end{tabular}

FFDW, fat-free dry weight.

Values significantly different from group 1 value; ${ }^{*} P<0 \cdot 05 ;{ }^{* *} P<0.001$ (Student's $t$ test),

$\dagger$ For details of groups, see Table 1 .

$\ddagger$ Initial values for FFDW and fat were calculated from the weight of individual animals at the start of the experiment and the carcass composition values from control animals killed at this time. In these control animals mean $( \pm \mathrm{SE})$ values obtained were $(/ \mathrm{kg}$ body-weight $)$ body water $69 \cdot 07 \pm 0 \cdot 15$, FFDW $25 \cdot 22 \pm 0 \cdot 06$, fat $5 \cdot 85 \pm 0 \cdot 22$.

responsible for the limited growth of most of the rats. Protein excess, defined as dietary protein not used for either maintenance or growth, was close to zero in animals of groups $1-5$, but in group 6 rats, $1.8 \mathrm{~g}$ of protein could not be accounted for in this way. Rats in groups 3,4 and 5 seemed to be more efficient in protein utilization than those fed $a d$ lib. On the other hand, the results show clear evidence of excessive energy intakes in all but the most-severely-restricted group. As the percentage of fat in the carcass of rats in groups 1-4 had increased above the baseline value of $5 \cdot 85 \pm 0 \cdot 22$, the energy represented by this rise has been added to that dissipated to give the total excess energy eaten. For example, it can be seen that animals fed on the P:E 0.03 diet ad lib. consumed on average $2955 \mathrm{~kJ}$ energy, of which $452 \mathrm{~kJ}$ was deposited as fat and $879 \mathrm{~kJ}$ dissipated. As the energy intake was reduced, this surplus decreased until eventually, in group 6, consumption was in fact less than the estimated maintenance requirement.

A further indication that the high energy consumption of these animals was an excess, and not an extra requirement for maintenance at times of low protein intake was provided by the thyroid-hormone $T_{3}$ results, which are shown in Fig. 1. Plasma concentrations of 


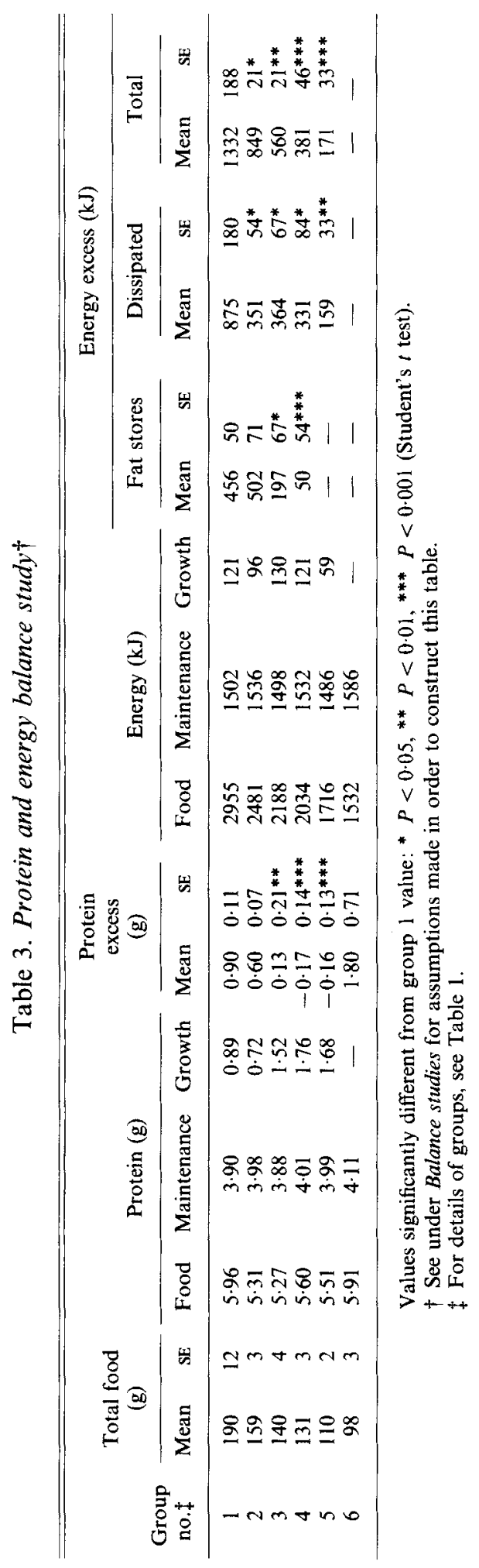




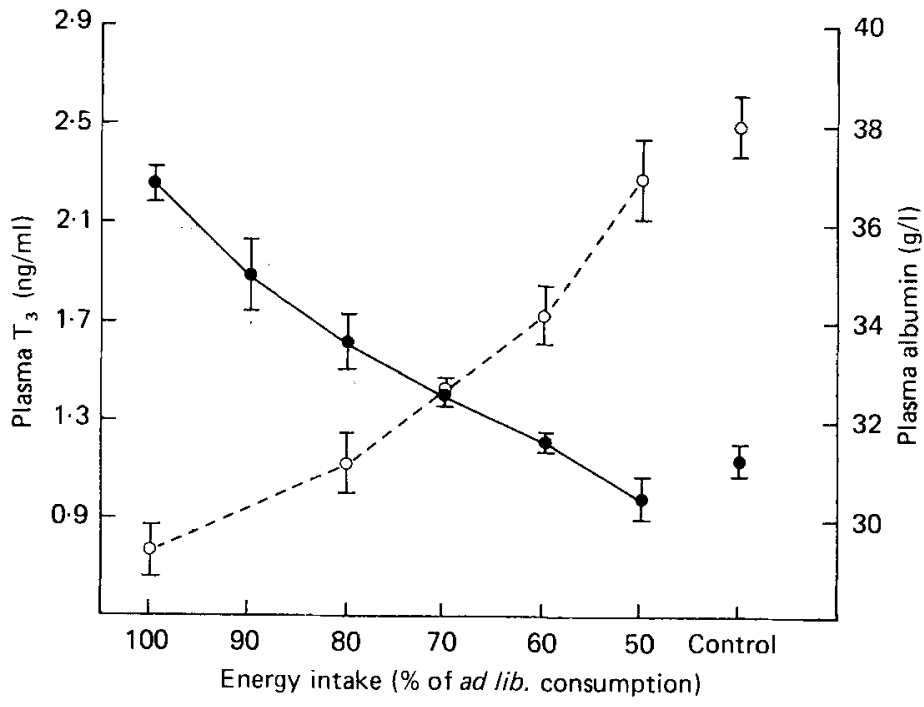

Fig. 1. Relationship between plasma $T_{3}$ and albumin concentrations with energy restriction at constant protein intake. Values are means and their standard errors for groups of five rats. albumin.

this hormone in rats of groups $1-5$ were elevated above those seen in normal well-fed animals of similar age. The highest values, associated with both the greatest dietary energy excess and the highest rate of energy dissipation was seen in group 1, and concentrations fell as the energy surplus was decreased by dietary restriction. In group 6 rats, the plasma $\mathrm{T}_{3}$ value was below normal and was thus in keeping with the primary energy deficiency indicated by the balance study.

A highly-significant correlation was found between plasma $T_{3}$ concentration and the amount of energy dissipated $(r 0.78, P<0.001)$, but the relationship between the hormone level and total energy excess was even stronger $(r 0.91, P<0.001)$.

Fig. 1 also demonstrates an important relationship between plasma albumin concentration and the level of energy restriction. Although there were no differences in over-all growth rates or gain in FFDW of rats in groups 1-5, plasma albumin concentration increased as energy consumption decreased, despite the constant protein intake. The highest albumin concentration was seen in rats restricted to $50 \%$ of the ad lib. energy intake, and this was not significantly different from the mean $( \pm \mathrm{SE})$ value of $38.0 \pm 0.6 \mathrm{~g} / 1$ observed in wellfed control animals.

\section{DISCUSSION}

The results demonstrate that the restricted growth of rats given ad lib a diet of P:E 0.03 was due entirely to an insufficient protein intake. Furthermore, the results show that, on the level of protein eaten by these animals, i.e. $0.41 \mathrm{~g} / \mathrm{d}$ per $\mathrm{kg}$ body-weight, energy consumption could be restricted to at least $60 \%$ of the ad lib. intake without reducing growth rates, or the gain in FFDW.

The explanation for the absence of an effect of energy reduction can be seen in the balance study where it is clear that rats in groups 1-5 were all consuming energy in excess of their requirements despite the 'restricted' intakes of groups 2-5. Group 1 animals, for example, ate $2955 \mathrm{~kJ}$ food during the $14 \mathrm{~d}$ experimental period, but only $1623 \mathrm{~kJ}$, i.e. approximately $55 \%$ of this was actually needed for maintenance and the limited amount of growth allowed 
by the low protein intake. Thus energy consumption in these animals was approximately $82 \%$ in excess of requirements so, clearly, even a $60 \%$ reduction of this level of intake (group 5 animals) would still provide more than adequate amounts of energy. Such high intakes could be expected to result in raised body fat stores and indeed an increase in the proportion of body fat was observed in the rats of groups $1-4$. These rises, however, could only account for part of the excess energy consumption. Again using group 1 as an example, $34 \%$ of the surplus energy had been utilized in this way, and the remainder dissipated presumably by the mechanism of diet-induced thermogenesis (Miller \& Payne, 1962; Stirling \& Stock, 1968).

The fact that rats fed on protein-deficient diets do have energy surplus to their requirements makes the elevated plasma $T_{3}$ concentration, which we and others (Edozien et al. 1978; Tulp et al. 1979) have observed in such animals, more understandable. Plasma levels of this hormone invariably rise during hyperphagia, and there is evidence to indicate that it plays some part in stimulating thermogenesis (Danforth et al. 1979). Our results suggest that the plasma $T_{3}$ concentration does in fact give a good indication of the excess energy eaten and the amount eventually dissipated. Only in the most-severely-malnourished animals was the plasma $T_{3}$ value below the level seen in well-fed controls. Rats in this group differed from the others as they lost both body-weight and FFDW during the experimental period. Moreover, the balance study indicated that energy, rather than protein, had become the primary deficiency limiting growth. This result is therefore in keeping with previous reports that reduced plasma $T_{3}$ levels occur under conditions of dietary energy restriction (Jung et al. 1980).

It can be seen in Fig. 1 that plasma $T_{3}$ concentration would reach the level found in control animals at a level of energy restriction between 50 and $60 \%$. This would clearly be very close to the point at which there would be no dietary energy excess, and where the relative extents of protein and energy restriction were equal.

A correct knowledge of the energy status of animals fed on diets of low $P: E$ is important as it makes a number of observations more easily understood, e.g. the reduction in gluconeogenesis in protein-deficient rats reported by Heard et al. (1977) is to be expected as the pathway is clearly not needed. However, the results are of greater importance in defining the impact of energy intake on the appearance of classical symptoms of kwashiorkor. Although dietary protein consumption remained constant, plasma albumin concentration varied with energy intake. It was lowest when the food contained the greatest excess of energy, and increased towards normal as this surplus was reduced by dietary restriction. Similar changes in albumin levels have been reported previously in rats receiving $50 \%$ of ad lib. intakes of low-protein diets (Coward et al. 1977), but those studies showed that other metabolic features characteristic of protein deficiency were also improved by this treatment. Plasma amino acids returned to a more normal pattern, the non-essential:essential amino acid value decreased and evidence of inappropriate body protein distribution, i.e. 'dysadaptation' (Gopalan, 1968), disappeared. More recent results show that the rate of albumin synthesis was higher in hepatocytes isolated from rats fed on low-protein diets in restricted amounts than from those fed on the same diet ad lib. (J. E. Smith \& P. G. Lunn, unpublished results). The suggestion made by Coward et al. (1977) that the reason for these changes was a switch from primary protein deficiency in the ad lib. animals to primary energy deficiency in the $50 \%$-restricted group has been confirmed by the present results. It is also known that rats fed on reduced amounts of adequate-protein diets do not show metabolic features of protein deficiency (Lunn \& Austin, 1982).

The slight but significant improvement in protein utilization when energy intake was reduced to 80,70 , or $60 \%$ of the ad lib. consumption was an unexpected finding. It is possible 
that this effect occurred because of an increased requirement for protein to deal with the excessive energy intake of the ad lib.-fed animals, or by an unavoidable increase in amino acid oxidation as a result of the high rate of thermogenesis. It is, nevertheless, also feasible that this small difference is an artefact resulting from one of the assumptions made in estimating the carcass composition. There is good evidence that the calculation of body fat and FFDW from measurements of body water remains valid over a wide range of conditions, e.g. in normal rats of differing weight (Rothwell \& Stock, 1979), in lean and obese mice (Jagot et al. 1980) and in protein-deficient and starved rats (Mendez \& Kollias, 1977). However, the assumption that the proportion of protein in FFDW also stays constant under various conditions is probably not entirely correct and could thus be a source of error. Consequently, it would be unwise to draw any firm conclusions from this particular result without confirmation of the findings by direct body protein measurements.

Although the plasma concentrations of $T_{3}$ and albumin both change in response to the energy intake, the results do not indicate any cause and affect relationship, but such a possibility cannot be ruled out at present. Thyroid hormones do stimulate muscle protein synthesis (Brown et al. 1981) and in this respect have an effect similar to insulin, but the effects of the two hormones on protein degradation are probably different (Jefferson et al. 1977; Flaim et al. 1978). Moreover, low plasma albumin concentrations are usually associated with low, not high, thyroid hormone values (Peavy et al. $1981 a, b$ ). Thus further work is clearly required to show whether the changes in $T_{3}$ concentration can be implicated in the same way as insulin and the corticosteroids in the development of hypoalbuminaemia. Nevertheless, whatever the mechanism proves to be, it seems that a major part of the reduction in plasma albumin and, perhaps, the appearance of other abnormalities seen in animals fed on the low-protein diets develop as a consequence of the metabolic response to excess dietary energy.

This rat model clearly provides considerable support for the traditional explanation of the aetiology of kwashiorkor (Whitehead \& Alleyne, 1972; Coward \& Lunn, 1981). The results are in keeping with the more frequent occurrence of this form of protein-energy malnutrition in those areas of the world where energy foods are in plentiful supply relative to protein food availability.

\section{REFERENCES}

Brown, J. G., Bates, P. C., Holliday, A. \& Millward, D. J. (1981). Biochem. J. 194, 771.

Canolty, N. L. \& Koong, L. J. (1976). J. Nutr. 106, 1202.

Coward, W. A. \& Lunn, P. G. (1981). Br. med. Bull. 37, 19.

Coward, W. A., Whitehead, R. G. \& Lunn, P. G. (1977). Br. J. Nutr. 38, 115.

Danforth, E. Jr, Horton, E. S., O'Connell, M., Sims, E. A. H., Burger, A. G., Ingbar, S. H., Braverman, L. \& Vagenakis, A. G. (1979). J. clin. Invest. 64, 1336.

Edozien, J. C., Niehaus, N., Mar, M.-H., Makoui, T. \& Switzer, B. R. (1978). J. Nutr. 108, 1767.

Evans, E. \& Miller, D. S. (1968). Proc. Nutr. Soc. 27, 121.

Flaim, K. E., Li, J. B. \& Jefferson, L. S. (1978). Am. J. Physiol. 235, E231.

Gopalan, C. (1968). In Calorie Deficiencies and Protein Deficiencies, p. 49 [R. A. McCance and E. M. Widdowson, editors]. London: Churchill.

Heard, C. R. C., Frangi, S. M., Wright, P. M. \& McCartney, P. R. (1977). Br. J. Nutr. 37, 1.

Jagot, S. A., Webb, G. P., Rogers, P. D. \& Dickerson, J. W. T. (1970). IRCS Med. Sci. 8, 93.

Jefferson, L. S., Li, J. B. \& Rannels, S. R. (1977). J. biol. Chem. 252, 1476.

Jung, R. T., Shetty, P. S. \& James, W. P. T. (1980). Clin. Sci. 58, 183.

Lunn, P. G. \& Austin, S. (1982). Ann. Nutr. Metab. (In the Press.)

Lunn, P. G., Whitehead, R. G. \& Baker, B. A. (1976). Br. J. Nutr. 36, 219.

Mendez, J. \& Kollias, J. (1977). J. appl. Physiol. 42, 731.

Miller, D. S. \& Payne, P. R. (1962). J. Nutr. 78, 255.

Northam, B. E. \& Widdowson, G. W. (1967). Ass. Clin. Biochem. tech. Bull. no. 11.

Pace, N. \& Rathbun, E. N. (1945). J. biol. Chem. 158, 667.

Peavy, D. E., Taylor, J. M. \& Jefferson, L. S. (1981 a). Am. J. Physiol. 240, E18. 
Peavy, D. E., Taylor, J. M. \& Jefferson, L. S. (1981 b). Biochem. J. 198, 289.

Rothwell, N. J. \& Stock, M. J. (1979). Br. J. Nutr. 41, 625.

Sheng, H.-P. \& Huggins, R. A. (1979). Am. J. clin. Nutr. 32, 630.

Stirling, J. L. \& Stock, M. J. (1968). Nature, Lond. 220, 801.

Tulp, O. L., Krupp, P. P., Danforth, E. Jr. \& Horton, E. S. (1979). J. Nutr. 109, 1321.

Whitehead, R. W. \& Alleyne, G. A. O. (1972). Br. med. Bull. 28, 72. 